\title{
KUALITAS HIDUP PADA KOMUNITAS HIV DAN AIDS LELAKI SEKS LELAKI
}

\author{
Quality Of Life In The HIV/ AIDS Community Male Sex Male
}

\author{
I Ketut Buana Yasa \\ Mahasiswa Program Studi S1 Keperawatan, STIKES Bina Usada Bali, Badung, Bali, Indonesia \\ Korespondensi : buanayasa@yahoo.co.id
}

\begin{abstract}
ABSTRAK
Human Immunodeficiency Virus (HIV) dan Acquired Immunodeficiency Syndrome (AIDS) merupakan salah satu masalah kesehatan yang menjadi perhatian seluruh dunia.Sejak pertama kali ditemukan hingga saat ini, jumlah penderita HIV dan AIDS mengalami peningkatan, salah satunya disebabkan oleh meningkatnya jumlah penderita pada komunitas lelaki seks dengan lelaki (LSL). Adapun tujuan dari penelitian ini adalah untuk memperoleh pemahaman yang mendalam tentang kualitas hidup ODHA pada komunitas LSL. Jenis penelitian yang digunakan adalah penelitian kualitatif dengan pendekatan fenomenologis. Proses pengumpulan data dilakukan dengan cara wawancara mendalam (indepth interview) dengan 5 partisipan dari komunitas LSL. Hasil wawancara yang diperoleh ditranskrip dan dianalisa. Hasil analisa memunculkan 4 tema yang dibahas di sini yaitu kualitas tidur yang tidak terpenuhi, menghargai hidup setelah didiagnosis HIV, butuh dukungan dari orang terdekat dan mendekatkan diri dengan Tuhan. Kajian tentang keempat tema tersebut sangat berguna sebagai informasi bagi ODHA pada komunitas LSL untuk meningkatkan kualitas hidupnya.
\end{abstract}

Kata kunci: HIV/AIDS, LSL, kualitas hidup

\section{ABSTRACT}

Human Immunodeficiency Virus (HIV) and Acquired Immunodeficiency Syndrome (AIDS) are health problems that are of concern to the whole world. Since they were first discovered until now, the number of HIV and AIDS sufferers has increased, one of which is due to the increasing number of sufferers in the sex with men (MSM) community. The purpose of this study was to gain a deep understanding of the quality of life of PLWHA in the MSM community. This type of research is qualitative research with a phenomenological approach. The data collection process was carried out by means of in-depth interviews with 5 participants from the MSM community. The results of the interviews obtained were transcribed and analyzed. The results of the analysis raised 4 themes discussed here, namely unfulfilled sleep quality, respect for life after being diagnosed with HIV, needing support from people closest to and being closer to God. The study on the four themes is very useful as information for PLWHA in the MSM community to improve their quality of life.

Keywords: HIV.AIDS, MSM, kualitas hidup 


\section{PENDAHULUAN}

Human Immunodeficiency Virus (HIV) dan Acquired Immunodeficiency Syndrome (AIDS) merupakan salah satu masalah kesehatan yang menjadi perhatian seluruh dunia. Sejak pertama kali ditemukan hingga saat ini, jumlah penderita HIV dan AIDS mengalami peningkatan. Sampai tahun 2016 diperkirakan terdapat 36,7 juta orang hidup dengan HIV dan 1,8 juta orang merupakan infeksi baru, angka kejadian AIDS diperkirakan 19,5 juta. Kematian akibat AIDS 1 juta orang (UNAIDS, 2017). Di Indonesia kasus HIV mencapai 291.129 orang, dengan jenis kelamin laki-laki sebanyak 168.254 orang dan perempuan sebanyak 122.875 orang. Kasus AIDS mencapai 106.965 orang dengan jenis kelamin laki-laki sebanyak 61.130 orang dan perempuan sebanyak 35.869 orang, tidak melaporkan jenis kelamin sebanyak 9.966 orang. Jumlah orang yang meninggal karena AIDS sebanyak 15.686 orang (Kementerian Kesehatan Republik Indonesia, 2018).

Provinsi Bali menempati peringkat ke 6 jumlah kasus HIV setelah DKI Jakarta, Jawa Timur, Jawa Barat, Papua dan Jawa Tengah serta peringkat ke 5 kasus AIDS setelah Papua, Jawa Timur, DKI Jakarta dan Jawa Tengah. Kasus HIV mencapai 17.560 orang, dan AIDS mencapai 7.456 orang (Kementerian Kesehatan Republik Indonesia, 2018). Di Kabupaten Badung dilaporkan kasus HIV sebanyak 1.819 dan AIDS sebanyak 1.199 orang (Dinas Kesehatan Kabupaten Badung, 2017).

Bertambahnya jumlah penderita HIV dan AIDS, salah satunya disebabkan oleh meningkatnya jumlah penderita pada komunitas lelaki seks dengan lelaki (LSL). Di Indonesia kasus HIV dan AIDS pada komunitas LSL tahun 2018 tercatat 41.380 kasus HIV, 6.130 kasus AIDS. Di Provinsi Bali dilaporkan sejak tahun 2010 sampai Maret 2018 tercatat 2.199 kasus HIVdan 346 kasus AIDS (Kementerian Kesehatan Republik Indonesia, 2018). Di Kabupaten Badung pada tahun 2015 sebanyak 152 kasus, tahun 2016 sebanyak 146 kasus dan tahun 2017 sebanyak 154 kasus (Dinas Kesehatan Kabupaten Badung, 2017). Kasus HIV dan AIDS pada komunitas LSL di Klinik Voluntary Counselling and Testing
(VCT) Sekar Jepun Rumah Sakit Umum Daerah (RSUD) Kabupaten Badung Mangusada sebanyak 487 orang yang sebagian besar berada di salah satu klinik satelit antiretroviral (ARV) (Rumah Sakit Daerah Mangusada, 2018).

Meningkatnya orang dengan HIV dan AIDS (ODHA) pada komunitas LSL mengakibatkan dampak biologis, psikologis, sosial-ekonomi, dan spiritual. Beberapa masalah yang ditimbulkan seperti penurunan berat badan terjadi secara drastis, munculnya infeksi oportunistik (IO), dan penurunan kemampuan dalam aktivitas sehari-hari (Pardita \& Sudibia, 2014). Serangkaian stigma, diskriminasi, penolakan dan penyerangan oleh oknum tertentu terkait gerakan lesbian gay biseksual transgender (LGBT) mengakibatkan ODHA mengalami tekanan, stres, depresi, dan merasa kurangnya dukungan sosial (Pardita \& Sudibia, 2014). Diskriminasi pada ODHA komunitas LSL mengakibatkan keterbatasan mendapatkan pekerjaan. Keadaan ini menyebabkan meningkatnya pengangguran, mengurangi kesejahteraan ODHA pada komunitas LSL. Hal ini menjadi sebuah tantangan bagi ODHA pada komunitas LSL, sehingga ODHA selalu berpikiran negatif terhadap masalah yang dihadapi, termasuk tentang penyakitnya. ODHA pada komunitas LSL berasumsi jika telah dinyatakan HIV positif maka hidupnya sudah berakhir. Keadaan ini sangat berpengaruh terhadap kualitas hidup ODHA pada komunitas LSL (Mardia, Ahmad, \& Riyanto, 2017).

Berdasarkan penelitian yang dilakukan oleh Mardia et al. (2017) disebutkan pada ODHA mengalami masalah yang komprehensif, salah satunya adalah masalah kualitas hidup. Kualitas hidup merupakan suatu ide yang abstrak yang tidak terkait oleh tempat atau waktu, bersifat situasional dan meliputi berbagai konsep. Kualitas hidup juga merupakan sebuah konsep multidimensi yang luas, dimana termasuk aspek positif maupun negatif dari kehidupan. World Health Organization (WHO) menyebutkan kualitas hidup sebagai persepsi individu terhadap posisinya dalam kehidupan sesuai dengan kontek sistem nilai dan budaya tempat mereka tinggal, serta 
hubungannya dengan tujuan, harapan, standar, dan perhatian mereka. Kualitas hidup dipengaruhi oleh kondisi fisik, psikologis, tingkat kemandirian, hubungan sosial, kepercayaan,dan hubungan dengan lingkungan (Muhammad, Shatri, Djoerban, \& Abdullah, 2017).

Penelitian Haroen, Juniarti, \& Windani (2008), pada enam orang partisipan bahwa kualitas hidup wanita dengan HIV dan AIDS serta wanita pasangan penderita HIV dan AIDS di Kabupaten Bandung Barat, secara umum tiga dari enam partisipan menyatakan kualitas hidup tidak ada perubahan, satu orang partisipan menyatakan kualitas hidup lebih baik, satu orang partisipan menyatakan kualitas hidupnya menurun, sedangkan satu orang partisipan masih dalam fase bingung dan terlihat masih tertutup (Haroen et al., 2008). Hasil studi pendahuluan tanggal 2 agustus 2018 di Klinik VCT Sekar Jepun RSUD Kabupaten Badung Mangusada dari 10 orang LSL yang diwawancari 7 orang memiliki kualitas hidup yang buruk. Dari ketujuh partisipan tersebut mengatakan salah satu faktor penyebab kualitas hidupnya buruk karena keterlambatannya mengakses layanan HIV dan AIDS. Dari hasil studi literatur didapatkan penelitian tentang kualitas hidup ODHA, belum banyak dilakukan pada komunitas LSL dengan HIV dan AIDS. Berdasarkan fenomena tersebut maka diperlukan sebuah penelitian yang mempelajari kualitas hidup pada komunitas LSL dengan HIV dan AIDS di Klinik VCT Sekar Jepun RSUD Kabupaten Badung Mangusada.

\section{TUJUAN PENELITIAN}

Penelitian ini bertujuan memperoleh pemahaman yang mendalam tentang kualitas hidup ODHA pada komunitas LSL yang mencakup kualitas tidur, self-esteem, aktifitas sehari-hari, dukungan sosial, aktifitas seksual, hubungan LSL dengan lingkungannya, serta gambaran nilai dan kepercayaan yang dimiliki LSL setelah didiagnosa HIV positif di Klinik VCT Sekar Jepun RSUD Kabupaten Badung Mangusada.

\section{METODE PENELITIAN}

Desain

Jenis penelitian yang digunakan adalah penelitian kualitatif dengan pendekatan fenomenologis. Penelitian kualitatif merupakan penelitian yang digunakan untuk menyelidiki, menemukan, menggambarkan, dan menjelaskan kualitas atau keistimewaan dari pengaruh sosial yang tidak dapat dijelaskan, diukur atau digambarkan melalui pendekatan kuantitatif, sedangkan pendekatan fenomenologis merupakan metode yang menginformasikan pengalaman hidup individu secara universal.

\section{Populasi dan Partisipan}

Populasi dalam penelitian ini adalah semua LSL dengan HIV dan AIDS di Klinik VCT Sekar Jepun RSUD Kabupaten Badung Mangusada. Jumlah partisipan yang diambil dalam penelitian ini adalah tiga orang. Kualitas hidup yang ingin peneliti dapatkan dari penelitian ini adalah pengalaman batin yang bermakna dan mendalam tentang HIV dan AIDS. Untuk itu, subjek penelitian harus memenuhi kriteria yaitu klien di diagnosa menderita HIV dan AIDS oleh dokter, klien merupakan LSL, klien termasuk ke dalam usia dewasa, keadaan umum klien baik, klien dapat berkomunikasi dengan baik dan bersedia menjadi partisipan. Pengambilan subjek penelitian dengan menggunakan tehnik snowball.

\section{Tempat dan Waktu Penelitian}

Pengambilan data penelitian ini dilakukan di Klinik VCT Sekar Jepun RSUD Kabupaten Badung Mangusada selama 2 minggu.

\section{Instrumen dan Prosedur Pengukuran}

Teknik pengumpulan data yang digunakan untuk memperoleh data mengenai kualitas hidup ODHA pada komunitas LSL, dilakukan dengan menggunakan teknik wawancara mendalam (indepth interview) kepada partisipan. Wawancara dilakukan secara tidak terstruktur atau dalam bentuk pertanyaan terbuka. Waktu yang ditetapkan untuk wawancara mendalam kurang lebih selama enam puluh menit, dengan perincian 
lima menit pertama tahap awal untuk pembukaan. Tahap kedua, selama empat puluh lima menit, merupakan tahap kerja untuk wawancara sesuai topik yang telah disepakati dan mengarah kepada wawancara mendalam mengenai pengalaman hidup partisipan tentang HIV dan AIDS dilihat dari segi bio, psiko,sosial dan spiritual klien. Tahap terakhir selama sepuluh menit untuk melakukan klarifikasi pernyataan klien yang dianggap penting dan memberi kesempatan kepada partisipan untuk mengungkapkan hal-hal yang ingin diungkapkan partisipan. Namun waktu yang digunakan selama wawancara disesuaikan dengan kondisi partisipan. Setelah wawancara, peneliti menyimpulkan beberapa jawaban kunci yang muncul ketika wawancara, dan menanyakan kepada partisipan apakah kesimpulan yang dibuat peneliti benar.

\section{Analisa Data}

Analisis data dilakukan selama pengumpulan data di lapangan dan setelah semua data terkumpul dengan teknik analisis model interaktif. Analisis data berlangsung secara simultan yang dilakukan bersamaan dengan proses pengumpulan data dengan alur tahapan: pengumpulan data (data collection), reduksi data (data reduction), penyajian data (data display), dan kesimpulan atau verifikasi (conclution drawing \& verifying).

\section{HASIL PENELITIAN}

\section{Karakteristik Responden}

Partisipan yang berpartisipasi dalam penelitian ini sebanyak 5 orang. Semua partisipan merupakan klien di Klinik VCT Sekar Jepun RSUD Kabupaten Badung Mangusada pada komunitas LSL. Semua partisipan yang ikut serta dalam penelitian ini berjenis kelamin laki-laki, dengan rentang usia 25 sampai dengan 30 tahun. Pendidikan terakhir partisipan bervariasi dari SMA sampai sarjana. Dari lima partisipan 3 orang beragama Islam, 1 orang beragama Hindu dan 1 orang beragama Kristen. Pekerjaan partisipan juga bervariasi ada sebagai karyawan swasta dan wiraswasta. Lama terdiagnosis HIV positif bervariasi dari satu tahun sampai 5 tahun yang lalu. Semua partisipan terpapar virus HIV melalui hubungan seksual lewat anal.

\section{Kualitas Tidur Yang Tidak Terpenuhi}

Kualitas tidur yang baik sangat dibutuhkan oleh semua orang karena ini sangat berkaitan dengan kesehatan fisik dan mental. Dengan kualitas tidur yang baik kita dapat meningkatkan kesehatan fisik dan kesehatan emosional. Sebagian partisipan mengatakan mengalami gangguan tidur setelah didiagnosa HIV, tetapi dengan rentang waktu yang bervariasi, dari waktu yang singkat sampai dengan waktu yang cukup lama. Pertanyaan ini diajukan kepada partisipan agar diketahui tentang gangguan tidur yang dialami oleh partisipan setelah didiagnosa HIV. Empat dari 5 partisipan yang diwawancarai mengatakan mengalami gangguan tidur setelah didiagnosa HIV dari yang ringan sampai berat, sedangkan 1 partisipan mengatakan kualitas tidurnya biasa saja.

"Untuk awalnya waktu pas pertama dengar HIV positif otomatis langsung kaget,syok tidak percaya koq bisa sampai kena seperti ini, nyesel marah sama diri sendiri kecewa semua rasanya campur aduk. Satu..Kemudian kalau untuk mau dibawa tidurnya itu karena waktu hari pertama barusan dengar dari itu masih kebawa, jadi otomatis masih pikiran kesana kemari mikir yang macem-macem apa segala macem. Tapi ketika udah sampai nangis setelah nangis, capek langsung tidur"( $p 1)$.

Partisipan selanjutnya juga mengalami hal sama yaitu gangguan tidur saat didiagnosa HIV positif. Dimana hambatan utama berkaitan dengan tidurnya karena memikirkan kedepannya apakah masih bisa hidup sehat.

"Tidak nyenyak tidur sering terjaga pas malam-malam. Pas tidur itu saya minta dijaga. kepikiran saja kenapa sampai kena ,terus masih bisa untuk kedepannya masih bisa untuk hidup sehat apa ga gara-gara penyakit inin" (p2). 
"Saya ga bisa tidur tenang karena memikirkan masa depan saya masa depannya" (p3).

\section{Menghargai hidup setelah didiagnosis HIV}

Sesuai tujuan khusus berkaitan dengan self-esteem dan aktifitas sehari-hari LSL setelah di diagnosis HIV didapatkan tema menghargai hidup. Sebagian besar partisipan mengatakan setelah terinfeksi HIV dan membuat gangguan psikologis, tapi hampir semua partisipan tetap menganggap penyakit yang diderita merupakan akibat kesalahan yang mereka lakukan. Partisipan merasa optimis dapat menatap masa depannya serta menghargai dirinya sendiri. Seperti diungkapkan oleh partisipan berikut ini :

"Pertama-tama sih setelah didiagnosa HIV positif saya pastinya syok, ya karena saya tahu diri saya sudah terjangkit masalah itu,...terjangkit penyakit itu. Tapi kembalinya lagi saya harus tetap semangat supaya saya juga dihargai orang lain. Karena kalau saya misalnya tidak menghargai diri saya pribadi orang lain pasti tidak menghargai diri saya sendiri dalam arti saya harus tetap menyembunyikan penyakit saya ini" ( $p 4)$.

Sedangkan partisipan lain mengatakan keterbukaan pada status HIV positif kepada orang lain, khusunya keluarga terdekat sangat membantu dalam meningkatkan semangat untuk tetap menghargai hidup.

"Perasaan malu ....malu sama keluarga, sama teman Cuma karena sakitnya sudah diketahui oleh keluarga, jadi perasaan malu itu jauh berkurang. Jadi biasa saja sih sebenarnya" ( $p 2)$.

Hal senada dikatakan oleh partisipan berikutnya yang mengatakan rasa optimis dan semangat itu timbul saat ada anggota keluarga atau teman yang dipercaya mengetahui status HIV partisipan dan memberi dukungan.

"Merasa..merasa yang sudah bener-bener saya akan dikucilkan. Saya udah ga ada harga lagilah, kayak jadi sampah masyarakat. Udah ngerasa yang sampai kayak gitu dan apa ya yang pokoknya benerbener terpuruk banget dengan keadaannya dengan awalnya itu. Untung ada teman dekat saya saya kasi tahu status HIV saya memberi semangat, support sehingga saya optimis dengan hidup saya" (p1).

\section{Konflik Diri Ketika Memutuskan Untuk Menjadi LSL dan Takut Menularkan Hiv Kepada Pasangan.}

Aktivitas seksual partisipan sebelum dan setelah di diagnosa HIV tidak terlalu ada perbedaan tetapi sebelum terdiagnosis HIV Partisipan mengalami pergulatan pribadi ketika memiliki ketertarikan dengan sesama jenis dimana partisipan mengalami beberapa proses dalam dirinya sebelum akhirnya memutuskan untuk total menjadi LSL, proses tersebut diantaranya penolakan perasaan (sensitisasi), kebingungan identitas (identity confusion), asumsi akan identitas (identity assumption), dan komitmen (commitment). Tapi setelah terdiagnosis HIV semua partisipan mengatakan merasa bersalah karena bisa menularkan HIV kepada pasangan. Berikut ini beberapa ungkapan dari partisipan berkaitan dengan orientasi seksualnya :

"Pada saat awalnya dulu sebenarnya ketertarikan itu ga ada tapi waktu dulu itu saya masih kecil jadi tiba-tiba diajak main sam teman-teman, kemudian dibawa dia sampai ke gitu. Waktu ketika saya kecil asal nerimo saja nah tapi lama kelamaan terbangunlah suatu kenikmatan seksual itu sama laki-laki gitu. Seiring dengan bertambahnya umur justru saya lebih masuknya ke kaum homo daripada ke kaum heterogen" (p1).

Partisipan berikutnya mengatakan ketertarikan itu dari kecil dan berkembang setelah dewasa. Berikut ungkapan partisipan tersebut :

"Karena memang dari kecil sudah memilih dengan sesame cuman pas melakukan hubungan itu setelah masa-masa perkuliahan. Kalau masalah tertarik sudah dari sekolah sudah tertarik pada sesame"( 22$)$.

"Sebenarnya ga ada alasan secara pasti tapi kenapa saya melakukan hubungan seks dengan sesama itu muncul secara tiba-tiba, Saya suka sama...apa namanya sesama lakilaki"(p3). 


\section{Butuh Dukungan dari Orang Terdekat}

Sesuai dengan tujuan khusus berkaitan dengan dukungan sosial dan hubungan LSL dengan lingkungan setelah di diagnosis HIV didapatkan tema butuh dukungan dari orang terdekat. Dukungan dan support yang berasal dari orang-orang terdekat partisipan, akan sangat membantu dalam menghadapi proses penyakit yang dialami oleh partisipan. Sebagian besar partisipan mengatakan pentingnya dukungan keluarga atau teman dekat dan petugas kesehatan (konselor) dalam membantu meningkatkan kepercayaan diri partisipan. Walaupun ada 1 orang partisipan yang merasa belum percaya diri mengungkapkan status HIV positif kepada orang lain, karena partisipan ini masih mempunyai anggapan kalau orang lain mengetahui statusnya dia akan dikucilkan. Berikut ini ungkapan partisipan tersebut :

"Dukungan dari keluarga ataupun dari teman dekat saya masih sepertinya karena saya belum membuka status saya yang sekarang" ( $p 3)$.

Berbeda dengan partisipan lainnya yang mengatakan merasa mendapat dukungan dari teman dekatnya setelah mengungkapkan status HIV positif. Keberanian mengungkapkan status HIV kepada beberapa teman dikarenakan partisipan berada di satu komunitas yang sama yaitu lelaki seks dengan lelaki.

"Jadi setelah terdiagnosis memang saya cerita ke beberapa orang dan apa ya, menurut mereka yang memang mau ga mau lakukan treatment jangan... jangan... jangan ... putus harapan sampai disini masih bilang pokonya kamu masih mudalah kalau misalnya kamu kalau kamu melakukan perawatan ya setidaknya kamu masih bisa apa ya...beraktifitas seperti biasa. Mereka sendiri juga bilang akan support juga dalam berbagai hal. Kemudian yang kamu pingin yang ga ngebuat kamu down apa setelah itu pokoknya bakalan di support" (p1).

Partisipan lainnya mengatakan hal sama berkaitan dengan dukungandari keluarganya dan teman-teman dekat di komunitasnya sangat membantu membangkitkan semangat hidupnya. Berikut pernyataannya :
"Kalau dari keluarga sih support yang pasti paling mensupport saya untuk sehat kembali itu. jangan dipikirkan penyakitnya, bagaimana harus sehat biar bisa kembali beraktifitas seperti semula. Kalau dari temen-temen kaget awalnya Cuma karena banyak temen juga yang sama penyakitnya seperti saya. Jadinya mereka kasi dukungan,kamu harus disiplin minum obat jaga kesehatan jangan menularkan sama orang lain, lagi berpikir positif “ ( 22$)$.

Dukungan dari teman dekat biasanya lebih dahulu dibandingkan dukungan oleh keluarga, karena komunitas LSL berani mengungkapkan sesuatu berkaitan dengan proses penyakitnya karena mempunyai latar belakang yang sama baik dari penyakitnya maupun orientasi seksualnya. Berikut pernyataan partisipan yang selalu mendapatkan support dari pasangannya.

"Kalau dukungan dari keluarga tahunya keluarga saya sehat-sehat aja. Tapi kalau dari temen dekat ada pada saat itu saya dirujuk dari puskesmas ke rumah sakit ini saya dari proses pendaftaran, tes lab, laboratorium dan juga saya dikasi masukanmasukan jangan terlalu banyak pikiran. Kalau kamu banyak pikiran..kalau kamu banyak pikiran otomatis akan mempengaruhi kehidupan dan kesehatan sehari-hari" ( $p 4)$.

Partisipan berikutnya mengatakan dukungan teman sangat bagus terutama dari komunitas.

"Untuk teman ini saling mensupport, untuk temen....dulu temen-temen waria menjauh tapi setelah mendapat pelatihan TB-HIV tahun 2012 nah dari situlah akhirnya dicampurlah ODHA dengan non ODHA. Setelah mereka tahu HIV bla....bla menular ga gampang malah temen-temen ODHA waria malah mensupport bagus" (p5).

\section{Lebih Mendekatkan Diri Kepada Tuhan}

Sebagian besar partisipan mengatakan bahwa sebelum terdiagnosis HIV kurang dalam hal pendekatan diri dalam spiritual. Setelah didiagnosis HIV mereka bisa belajar banyak tentang agama, memiliki kesempatan untuk bertobat kepada Tuhan dan menyadari kesalahan yang telah dilakukan. Pertanyaan yang diajukan dalam penelitian ini telah diusahakan lebih luas daripada agama, tetapi 
semua partisipan menghubungkan spiritualitas dengan agama. Semua partisipan mempunyai keinginan agar bisa lebih mendekatkan diri dengan Tuhan dan memohon ampunan atas kesalahan yang telah dilakukan. Karena selama ini semua partisipan mengatakan jauh dengan Tuhan dan banyak melakukan kesalahan. Dari 5 partisipan yang diwawancarai 4 partisipan mengatakan sebagian besar berdoa terfokus dengan proses pemulihan penyakitnya, tapi ada 1 partisipan yang mengatakan spiritualitasnya biasa saja setelah di diagnosis HIV.

Berikut pernyataannya :

"Untuk hal yang berkaitan dengan spiritual apa ya untuk intensitas beribadahnya sama seperti biasa tapi apa ya lebih..lebih kalau yang dari dulu apa kita cuman berdoa untuk hal-hal yang umum. Setelah terdiagnosis lebih..lebih ke saya mengungkapkan kepada Tuhan itu, ya Tuhan saya sekarang sudah tidak begini-begini tapi dengan status saya itu tolong bantu saya untuk bisa hadapi ini semua lebih ke apa ya curhat yang benerbener udah focus hal ini kalau yang sebelumnya berdoa ke yang umum-umum saja” ( 1$)$.

Partisipan yang lain mengatakan berbeda sekali berkaitan dengan siritualitasnya sebelum dengan setelah didiagnosis HIV. Partisipan ini baru 2 minggu pengobatan anti retroviral (ARV). Setelah didiagnosis HIV lebih sering mendekatkan diri kepada Tuhan. Berikut pernyataannya :

"Setelah didiagnosis jadi yang dulu-dulunya itu mungkin sembahyang pada hari-hari tertentu sekarang setelah didiagnosis jadi sering memohon pada Tuhan dan leluhur smoga diberikan kesehatan dan yang pasti sih smoga obatnya yang diberikan itu cocok kepada saya ya gitu-gitu aja” (p2).

Hal serupa diungkapkan oleh partisipan 4, partisipan ini mengatakan spitualitasnya jauh berubah setelah didiagnosa HIV. Selain itu partisipan sudah mulai menyadari kesalahan yang dilakukan selama ini berkaitan proses penyakitnya karena kesalahan sendiri. Berikut pernyataannya :

"Setelah saya positif dengan penyakit HIV ini pastinya spiritualitas atau keagamaan saya pastinya adalah perubahan sebelum dan sesudah terjangkit saya lebih mengingat kepada Tuhan saya bahwa saya meminta ampun diberi saya umur panjang bahwa supaya saya bisa menebus kesalahankesalahan yang kemaren ini. Saya tahu penyakit ini teguran buat saya supaya saya lebih mendekatkan diri kepada Tuhan".

"Pastinya setelah positif HIV lebih dengan Tuhan itu udah lebih dekat dibandingkan sebelum kena karena sebelum kena aku kan sehat sehat saja" (p4).

\section{PEMBAHASAN}

Penelitian ini menemukan 5 tema untuk mengungkapkan berkaitan dengan kualitas hidup ODHA pada komunitas LSL. Gambaran tentang kualitas hidup ODHA pada komunitas LSL khususnya tentang kualitas tidur terindentifikasi pada tema pertama yaitu kualitas tidur yang tidak terpenuhi sedangkan untuk mengetahui selfesteem,aktivitas sehari-hari LSL setelah didiagnosis HIV positif terindentifikasi pada tema kedua yaitu menghargai hidup setelah didiagnosa HIV positif. Aktivitas seksual LSL setelah didiagnosis HIV teridentifikasi pada tema ketiga yaitu konflik diri ketika memutuskan untuk menjadi LSL dan takut menularkan HIV kepada pasangan. Untuk mengetahui dukungan sosial dan hubungan LSL dengan lingkungan teridentifikasi pada tema keempat yaitu Butuh dukungan dari orang terdekat. Untuk mengetahui gambaran nilai dan kepercayaan yang dimiliki LSL setelah didianosis HIV positif teridentifikasi pada tema kelima yaitu lebih mendekatkan diri kepada Tuhan.

\section{Kualitas Tidur Yang Kurang Terpenuhi}

Hasil penelitian ini menemukan bahwa apa yang dirasakan oleh partisipan setelah didiagnosis HIV adalah kualitas tidur yang belum terpenuhi apalagi status HIV partisipan baru diketahui. Kelima Partisipan mengatakan bahwa penyebab gangguan tidur yang dirasakan akibat defresi yang dialami berkaitan dengan hasil tes HIV menunjukkan partisipan terinfeksi virus HIV. Walaupun sudah lama terdiagnosis HIV gangguan tidur itu sering terjadi disaat teringat dengan proses perjalanan 
penyakitnya. Partisipan mengatakan setelah didiagnosis HIV perasaan yang selalu menghantui baik karena takut stigma dan diskriminasi bisa diminimalisir sehingga bisa membantu mengatasi gangguan tidur yang sering dialami.

Penelitian Elfitri (2014) mengatakan gangguan kualitas tidur umumnya terjadi pada orang dengan HIV/AIDS. Kualitas tidur yang buruk bagi ODHA dapat mempengaruhi status kesehatan dan fungsionalnya. Adanya penurunan jumlah CD4, kecemasan dan kepatuhan terhadap terapi ARV diduga berhubungan dengan kualitas tidur pada ODHA. Orang dewasa membutuhkan waktu tidur 7-8 jam setiap hari, petugas kesehatan menyarankan bagi mereka yang ingin hidup sehat untuk menerapkan aturan ini pada kehidupannya. Karena ancaman yang terjadi akibat kurang tidur diantaranya memperburuk kondisi kesehatan tubuh. Berbagai penyakit akan menghampiri seperti penyakit jantung, tekanan darah tinggi, stroke, bahkan diabetes mellitus, selain itu akibat kurang tidur akan sering mengalami stres, sering marah-marah tanpa sebab yang jelas dan kelihatan kelelahan disela-sela waktu aktivitas seharihari (Kemenenterian Kesehatan RI, 2014).

Hal ini sejalan dengan yang dialami oleh hampir semua partisipan berkaitan dengan gangguan tidur yang dialami setelah didiagnosa HIV. Permasalahan tersebut sebagaian besar disebabkan oleh faktor stress yang berkaitan dengan proses penyakit yang dialami oleh partisipan. Walaupun gangguan tidur yang dialami sudah pelanpelan mulai berkurang tetapi kadang-kadang hal tesebut sulit dihilangkan kalau sewaktuwaktu terlintas ketakutan berkaitan dengan status HIV yang dideritanya.

\section{Menghargai hidup setelah didiagnosa HIV}

Kualitas hidup istilah popular yang menyiratkan keseluruhan rasa kesejahteraan, termasuk aspek kebahagiaan dan kepuasan dalam kehidupan secara keseluruhan. Ini lebih luas dan subyektif daripada spesifik dan obyektif (Billington, Landon, Krägeloh, \& Shepherd, 2010). Kualitas hidup dipengaruhi oleh kondisi fisik, psikologis, tingkat kemandirian, hubungan sosial, kepercayaan, dan hubungan dengan lingkungan. Coopersmith (1967) menjelaskan bahwa harga diri adalah evaluasi yang dibuat individu mengenai sesuatu yang berkaitan dengan dirinya, yang diekspresikan dalam suatu bentuk sikap setuju atau tidak setuju dan menunjukkan bahwa individu tersebut meyakini dirinya sendiri sebagai individu yang mampu, penting, dan berharga. Berkaitan dengan ini berdasarkan pengalaman di layanan setelah didiagnosa HIV komunitas LSL sering mendapatkan stigma ganda selain karena status HIV juga karena orientasi seksual yang dianggap menyimpang. Dari ke 5 partisipan hampir semuanya mengalami permasalahan ini, tetapi tekad dan semangat yang membuat partisipan tetap bisa bertahan dan bisa menjalankan kehidupan seperti sebelumnya.

Menurut penelitian Nugroho (2012), sebagian LSL ada yang mengalami konflik psikis karena dorongan homoseksual dalam dirinya. Konflik psikis tersebut antara lain menyebabkan perasaan bersalah, kesepian, malu, cemas, dan depresi. Perasaan akan hal-hal tersebut diduga menyebabkan jumlah LSL yang memiliki harga diri dengan kategori rendah dalam penelitian ini cukup besar. Aspek-aspek harga diri yang dominan negatif pada aspek mengenai kebanggaan terhadap diri sendiri, kepuasan terhadap diri sendiri, dan kemampuan diri mengerjakan sesuatu seperti yang dilakukan orang lain diprediksi bisa membantu ODHA pada komunitas LSL ini menghargai hidupnya. Begitu juga dengan aktivitas sehari-hari akan berdampak setelah partisipan didiagnosa HIV,dimana partisipan mengatakan timbul keraguan keputusasaan tidak bersemangat melaksanakan aktivitas sehari-hari setelah dirinya tahu terinfeksi HIV.

Temuan penelitian Hardiansyah, Amiruddin, \& Arsyad (2014) menyebutkan, pada dasarnya ODHA mampu melakukan kegiatan-kegiatan yang berhubungan dengan perawatan dan pengobatan secara fisik seperti berolahraga, tidur yang cukup, serta keteraturan mengkonsumsi obat. Responden yang merasakan hal tersebut adalah responden yang sudah lama terkena HIV dan AIDS serta sudah menjalani pengobatan ARV >1 tahun, bergabung di Kelompok 
Dukungan Sebaya (KDS) yang ada di puskesmas, sehingga karena banyaknya kesibukan mereka seakan melupakan bahwa sebenarnya mereka memiliki penyakit menular yang mematikan. Kegiatan ini mereka sadari dapat meningkatkan kesehatannya secara fisik karena terbukti, jika ODHA melakukan kegiatan ini mereka merasa produktif sehingga berdampak pada kualitas hidup ODHA itu sendiri.

Lubis, Sarumpaet, \& Ismayadi (2016) mengatakan menjadi ODHA merupakan suatu yang berat dalam hidup, dimana permasalahan yang kompleks selalu dihadapi setiap hari, bukan hanya berurusan dengan kondisi penyakit, tetapi kondisi penyakit yang disertai dengan stigma sosial yang sangat diskriminatif. Stigma dan diskriminasi ini seringkali menyebabkan menurunnya semangat hidup ODHA yang kemudian membawa efek dominan menurunnya kualitas hidup ODHA. Kualitas hidup pada pasien HIV dan AIDS sangat penting untuk diperhatikan karena penyakit infeksi ini bersifat kronis dan progresif sehingga berdampak luas pada segala aspek kehidupan baik fisik, psikologis, sosial, maupun spiritual. Dengan stigma dan diskriminasi ini bisa berdampak partisipan tidak akan menghargai hidupnya lagi. Berdasarkan pengalaman di layanan sebagian besar partisipan mengatakan membutuhkan semangat dan kemauan untuk bisa mengatasi permasalahan berkaitan dengan harga diri yang sangat berpengaruh terhadap aktivitas sehari-hari yang dilakukan. Partisipan mengatakan setelah dirinya didiagnosa HIV positif hidupnya tidak berakhir.

\section{Konflik Diri Ketika Memutuskan untuk Menjadi LSL dan Takut Menularkan HIV Kepada Pasangan.}

Partisipan mengalami konflik ketika memutuskan untuk menjadi homoseksual baik konflik internal maupun konflik eksternal. Konflik internal berupa pergulatan pribadi seputar perasaan akan identitas diri dan seksual, sedangkan konflik eksternal berupa masalah yang timbul didalam lingkungan keluarga dan sosial (Kusuma, 2012). Dewi \& Indrawati (2017) mengatakan beberapa subjek penelitian memiliki hambatan untuk menjadi heteroseksual. Subjek ditemukan memiliki ketidakmampuan dalam mengontrol dorongan seksual. Hurlock (2000) menyatakan bahwa remaja akan berusaha untuk mencari informasi mengenai seks, selain mencari pemahaman melalui literatur, mereka juga mengadakan percobaan melalui jalan masturbasi, bercumbu, atau bersanggama. Beberapa subyek penelitian mengalami kesulitan mengontrol untuk tidak melakukan onani selama kurang dari 6 bulan dan berhubungan dengan gay menjadikannya faktor sulit untuk merubah kebiasaan homoseksual. Begitu pun dengan subjek S yang berusaha tidak berhubungan dengan gay melalui akun palsu yang dibuat tidak dapat mengontrol dorongan untuk kembali berhubungan dengan gay. Subjek lainnya merasakan kenikmatan tersendiri bersetubuh dengan laki-laki pun merasa tak kuasa menahan dorongan seksual dan mempertahankan bersama dengan laki-laki. Ketidakmampuan beberapa subjek penelitian dalam mengontrol dorongan seksual dikarenakan persepsi kebutuhan seksual yang harus terpenuhi sehingga menjadikan subjek seolah tak berdaya mengontrol dorongan seksual.

\section{Dukungan dari Orang Terdekat}

Dukungan terhadap partisipan setelah didiagnosis HIV sebagian besar adalah berasal dari teman dekatnya terutama dari komunitas yang sama yaitu komunitas LSL. Karena sampai saat diwawancarai sebagian partisipan mengatakan belum terbuka dengan keluarganya berkaitan dengan status HIV nya dengan belum berani dikwatirkan berdampak dengan kondisi keluarganya. Setelah didiagnosa HIV partisipan mengatakan bergabung dengan suatu wadah dalam kelompok dukungan sebaya (KDS) khususnya komunitas LSL. Haq (2018), mengatakan selain terserang dari segi fisik penderita juga sering mengalami masalah psikologis, terutama kecemasan, depresi, rasa bersalah akibat status HIV dan orientasi seksual (homoseksual) yang masih menjadi pro dan kontra, marah bahkan sampai timbul dorongan untuk bunuh diri. Penderita juga mengalamai kesulitan dalam penyesuaian 
dirinya terkait dengan status barunya ini. Dalam kondisi seperti ini ODHA membutuhkan dukungan sosial. Keberadaan keluarga sebagai orang terdekat penderita akan sangat dibutuhkan. Keluarga diharapkan menjadi sumber dukungan utama bagi penderita karena keluarga yang senantiasa bisa di andalkan. Keluarga diharapkan mampu untuk memberikan dukungan-dukungan tersebut secara menyeluruh, sehingga perlu untuk diteliti apakah dukungan sosial ini sudah terpenuhi. Dukungan kepada ODHA merupakan dukungan emosional yang dapat diberikan oleh suami/istri, teman sebaya, anggota keluarga bahkan petugas kesehatan. Dukungan sosial ini berbeda dengan kontak sosial yang tidak selalu memberikan dukungan emosional (Videbeck, 2008).

Fauziyah, Shaluhiyah, \& Prabamurti (2018) dalam penelitiannya mengatakan banyak LSL remaja dengan HIV positif menyembunyikan jati dirinya sebagai remaja LSL dengan status HIV positif, dikarenakan secara tidak langsung mereka akan ada penolakan dari pasangan, keluarga, dan lingkungan diakibatkan oleh masih rendahnya informasi mengenai HIV dan AIDS pada remaja LSL dan masyarakat, mereka rata-rata tidak melanjutkan pendidikan kejenjang yang lebih tinggi, akibat malu dengan status HIVnya. Bagi individu yang positif terinfeksi HIV, menjalani kehidupannya akan terasa sulit karena dari segi fisik individu tersebut akan mengalami perubahan yang berkaitan dengan perkembangan penyakitnya. Pandangan dan sikap lingkungan terhadap orang yang terinfeksi HIV yang umumnya belum bisa menerima, takut, mendapatkan cap buruk, yang bisa berujung pada pengucilan serta diskriminasi membuat penderita semakin stress (Soetjinigsih, 2011). Disinilah peran orang terdekat seperti keluarga, teman dekat, pasangan memberikan dukungan sosial yang bisa membantu menumbuhkan semangat ODHA khususnya LSL untuk menjalankan hidupnya seperti penuturan sebagian partisipan dalam penelitian ini.

Khairunnisa (2015), melaporkan berbicara mengenai penyakit HIV dan AIDS pasti banyak masyarakat yang merasa takut dengan penyakit menular ini.Stigma negatif pun sangat melekat pada penderitanya. Tak jarang penderita HIV dan AIDS ini dikucilkan oleh masyarakat. Mereka dianggap sebagai manusia yang memiliki harapan hidup sedikit. Walaupun telah diketahui bentuk penyebaran HIV dan AIDS, masyarakat masih memandang bahwa dekat dengan seseorang pengidap HIV dan AIDS ini berbahaya atau mereka merasa takut tertular. Maka stigma negatif banyak didapatkan pengidap HIV dan AIDS atas tanggapan masyarakat tersebut. Stigma dan diskriminasi pada ODHA dapat terjadi di mana saja dan kapan saja, hal ini terutama dikarenakan stigma negatif yang dilekatkan pada ODHA, misalnya sampah masyarakat, pengguna narkotika, dan pelanggan lokalisasi. Bentuk lain dari stigma berkembang melalui internalisasi oleh ODHA dengan persepsi negatif tentang diri mereka sendiri. Stigma dan diskriminasi yang dihubungkan dengan penyakit menimbulkan efek psikologi yang berat tentang bagaimana ODHA melihat diri mereka sendiri, hal ini bias mendorong terjadinya depresi, kurangnya penghargaan diri dan keputusasaan. Stigma dan diskriminasi ini seringkali menyebabkan menurunnya semangat hidup ODHA yang kemudian membawa efek dominan menurunnya kualitas hidup ODHA. Berkaitan dengan dukungan sosial ini semua partisipan masih merasa beruntung dengan dukungan yang masih didapat dari orang dekatnya.

\section{KESIMPULAN}

Implikasi

Kualitas tidur yang dirasakan oleh klien LSL setelah didiagnosis HIV dan AIDS adalah berpikir dengan hal-hal positif agar bisa mendapatkan kualitas tidur yang baik. Self-esteem klien LSL setelah didiagnosis lebih menghargai makna hidup sebenarnya, menikmati hidup dan pasrah menerima keadaan sesuai takdir Tuhan. Aktifitas sehari-hari klien LSL setelah di diagnosis HIV dan AIDS tetap dilaksanakan seperti biasa demi memikirkan masa depannya. Dukungan sosial dari keluarga, teman dekat dan pasangan sangat membantu 
klien LSL dalam melewati masa-masa sulit setelah di diagnosis HIV dan AIDS. Aktifitas seksual klien LSL setelah di diagnosis HIV dan AIDS tetap seperti biasa dan belum ada niat untuk berubah ke orientasi heteroseksual. Hubungan klien LSL dengan lingkungannya setelah di diagnosis HIV dan AIDS tidak ada masalah karena sampai saat ini lingkungannya belum mengetahui status HIV dari klien LSL. Gambaran nilai dan kepercayaan klien LSL setelah di diagnosis HIV dan AIDS adalah lebih mendekatkan diri dan berserah kepada Tuhan.

Temuan data dalam penelitian dapat dijadikan sebagai bahan masukan bagi bagi profesi perawat dalam memberikan pelayanan keperawatan pada klien HIV dan AIDS khususnya komunitas LSL. Pengkajian terkait tanda atau gejala yang berkaitan dengan kebutuhan bio psiko sosial dan spiritual yang dapat mempengaruhi kualitas hidup klien HIV dan AIDS pada komunitas LSL dapat dilakukan lebih spesifik, seperti hubungan klien dengan dirinya sendiri, dengan orang lain dalam hal ini teman, pasangan atau keluarganya dan yang tidak kalah penting hubungan klien dengan Tuhan, mekanisme koping yang digunakan klien saat melawan penyakit yang dideritanya, bagaimana dukungan keluarga, teman dekatnya, pasangannya dan bagaimana hubungan dengan lingkungan.

\section{Keterbatasan}

Keterbatasan dalam pelaksanaan penelitian ini adalah hampir semua partisipan tempat tinggalnya jauh dari lokasi klinik VCT Sekar Jepun RSUD Kabupaten Badung Mangusada sehingga pada saat akan melakukan wawancara jauh hari kita sudah membuat perjanjian dengan partisipan. Hambatan lainnya adalah pemilihan waktu wawancara dan kesulitan partisipan mengatur jadwal libur.

\section{DAFTAR PUSTAKA}

Billington, D. R., Landon, J., Krägeloh, C. U., \& Shepherd, D. (2010). The New Zealand World Health Organization Quality of Life (WHOQOL) Group. Journal of the New Zealand Medical Association, 123(1315), 65-70.

Coopersmith, S. (1967). The antecedents of self-esteem. San Francisco: W. H. Freeman \& Co.

Dewi, G. A. Y., \& Indrawati, E. S. (2017). Pengalaman Menjadi Gay (Studi Fenomenologi pada Pria Homoseksual Menuju Coming Out). Journal of Chemical Information and Modeling, 7(3), 116-126.

Dinas Kesehatan Kabupaten Badung. (2017). Profil Kesehatan Kabupaten Badung. Badung.

Elfitri, R. (2014). Faktor-Faktor Yang Berhubungan Dengan Kualitas Tidur Pada Orang Dengan HIV/AIDS di Yayasan Lentera Minangkabau Support Padang Tahun 2014. Universitas Andalas.

Fauziyah, F., Shaluhiyah, Z., \& Prabamurti, P. N. (2018). Respon Remaja Lelaki Suka Lelaki (LSL) dengan Status HIV Positif terhadap Pencegahan Penularan HIV kepada Pasangan. Jurnal Promosi Kesehatan Indonesia, 13(1), 17.

Haq, N. Z. (2018). Analisis Dukungan Sosial Keluarga Pada ODHA di UPipi RSUD Dr Soetomo Surabaya. Surabaya: Program Studi Pendidikan Ners Universitas Airangga.

Hardiansyah, Amiruddin, R., \& Arsyad, D. S. (2014). Kualitas Hidup Orang Dengan HIV dan AIDS di Kota Makassar. Media Kesehatan Masyarakat Indonesia, 1-11.

Haroen, H., Juniarti, N., \& Windani, C. (2008). Kualitas Hidup Wanita Penderita Aids Dan Wanita Pasangan Penderita Aids Di Kabupaten Bandung Barat. Majalah Keperawatan Unpad, 10(18), 1-16.

Hurlock, E. B. (2000). Psikologi Perkembangan: Suatu Pendekatan Sepanjang Rentang Kehidupan. (Istiwidayati, Ed.). Jakarta: Erlangga.

Kemenenterian Kesehatan RI. (2014). Peraturan Menteri Kesehatan Republik 
Indonesia Nomor 87 Tahun 2014 Tentang Pengobatan Antiretroviral. Indonesia.

Kementerian Kesehatan Republik Indonesia. (2018). Laporan_HIV/AIDS TW 1 Tahun 2018. Jakarta.

Khairunnisa, D. A. (2015). Efektivitas Dukungan Sosial bagi ODHA (Orang Dengan HIV/AIDS) di Kelompok Dukungan Sebaya Kuldesak Kota Depok. Universitas Islam Negeri.

Kusuma, P. A. (2012). Konflik Diri dan Persepsi Homoseksual (Lesbian) terhadap Nilai-Nilai Spiritual. Universitas Muhammadiyah Surakarta.

Lubis, L., Sarumpaet, S. M., \& Ismayadi. (2016). Hubungan Stigma, Depresi Dan Kelelahan Dengan Kualitas Hidup Pasien Hiv/Aids Di Klinik Veteran Medan. Idea Nursing Journal, 7(1), 113.

Mardia, Ahmad, R. A., \& Riyanto, B. S. (2017). Kualitas hidup orang dengan HIV / AIDS berdasarkan kriteria diagnosis dan faktor lain di Surakarta. BKM Journal of Community Medicine and Public Health, 33(3), 147-152.

Muhammad, N. N., Shatri, H., Djoerban, Z., \& Abdullah, M. (2017). Uji Kesahihan dan Keandalan Kuesioner World Health Organization Quality of LifeHIV Bref dalam Bahasa Indonesia untuk Mengukur Kualitas Hidup Pasien HIV/AIDS. Jurnal Penyakit Dalam Indonesia, 4(3), 112.

Nugroho, A. (2012). Peran Faktor Harga Diri dan Pusat Pengendalian Diri Terhadap Perilaku Seksual Lelaki Seks dengan Lelaki di Jakarta Timur Hasil pada kelompok bahwa LSL dilakukan antar faktor personal, faktor lingkungan, menganalisis peran faktor personal dalam diri LSL. Jurnal Biotek Medisiana Indonesia, 1(1), 21-29.

Pardita, D. P. Y., \& Sudibia, I. K. (2014). Analisis Dampak Sosial, Ekonomi, dan Psikologis Penderita HIV AIDS di Kota Denpasar. Jurnal Buletin Studi Ekonomi, 19(2), 193-199.

Rumah Sakit Daerah Mangusada. (2018). Laporan Bulanan Perawatan HIV dan ART. Badung.

Soetjinigsih. (2011). Tumbuh Kembang
Remaja dan Permasalahannya. Jakarta: Sagung Seto.

UNAIDS. (2017). Global AIDS Update. World Health Organization. Geneva.

Videbeck, S. L. (2008). Buku Ajar Keperawatan Jiwa. Jakarta: EGC. 